\title{
PEMILIHAN METODE SEGMENTASI PADA CITRA ULTRASONOGRAFI OVARIUM
}

\author{
Eliyani $^{1)}$, Fakhlul Nizam ${ }^{2)}$ \\ ${ }^{1,2)}$ Jurusan Teknik Elektro- Universitas Muhammadiyah Gresik \\ 1eliyani@umg.ac.id, ${ }^{2}$ fakhlulnizam@umg.ac.id \\ JL. Sumatra No 101, Gresik 61121, Jawa Timur
}

\begin{abstract}
ABSTRAK
Penelitian ini membandingkan metode segmentasi untuk mengenali folikel pada citra ultrasonografi ovarium, metode segmentasi yang paling baik akan digunakan untuk proses perhitungan jumlah folikel. Penilaian kinerja metode segmentasi active contour dan active contour without edge dievaluasi menggunakan Probabilistic Rand Index (PRI) dan Global Consistency Error (GCE). Hasil penelitian ini menunjukkan metode segmentasi yang terbaik adalah active contour without edge karena memiliki nilai PRI lebih tinggi dan pada nilai GCE lebih rendah dari pada hasil metode segmentasi active contour.
\end{abstract}

Kata kunci: active contour, active contour without edge.

\begin{abstract}
This study compares the segmentation method to identify follicles on ovarian ultrasound images; the best segmentation method is used to calculate the number of follicles. The performance assessment of active contour and active contour without edge segmentation methods was evaluated using Probabilistic Rand Index (PRI) and Global Consistency Error (GCE). This study indicates that the best segmentation method is active contour without edge because it has a higher PRI value and a lower GCE value than the results of the active contour.
\end{abstract}

Keywords: active contour, active contour without edge.

\section{PENDAHULUAN}

National Survey of Family Growth menunjukkan persentase perempuan pada usia 15 - 44 tahun di Amerika mengalami gangguan fertilitas sebanyak 12,1\% [1]. Perempuan Indonesia berumur 30-34 tahun mengalami gangguan fertilitas sebanyak $15 \%$, usia 35 - 39 tahun mengalami gangguan fertilitas sebanyak $30 \%$, meningkat 55\% pada usia 40 - 44 tahun [2]. Riset kesehatan dasar pada tahun 2013, Badan
Penelitian dan Pengembangan Kesehatan Kementerian Republik Indonesia menyatakan pasangan infertilitas di Indonesia adalah 15 $25 \%$ dari seluruh pasangan yang ada sebanyak 98,3\% [3]. Berdasarkan data pada tahun 2017, Perhimpunan Fertilisasi In Vitro Indonesia, terdapat 2.055 wanita dan 1.712 pria yang mengalami gangguan fertilitas.

Gangguan fertilitas menyebabkan kesulitan memperoleh kehamilan, beberapa 
perempuan akan melakukan konsultasi dengan dokter kandungan untuk mengatasi gangguan fertilitas. Gangguan fertilitas dapat di ketahui dari hasil wawancara pasien tentang siklus masa subur, hasil laboratorium reproduksi serta hasil gambar ultrasonografi ovarium. Pemeriksaan cepat dan murah dapat dilakukan menggunakan ultrasonografi ovarium dibandingkan pemeriksaan di laboratorium [4]. Dokter menghitung secara manual jumlah folikel yang terlihat dari gambar ultrasonografi ovarium, pemantuan jumlah folikel sangat bermanfaat bagi wanita yang ingin progam hamil. Pasien sulit hamil jika memiliki jumlah folikel lebih dari 12 dengan ukuran kecil.

Keterbaruan pada penelitian ini adalah memilih metode segmentasi berdasarkan hasil analisis nilai Probabilistic Rand Index (PRI) dan Global Consistency Error (GCE) serta hasil segmentasi pada penelitian ini dapat menunjukkan jumlah folikel yang lebih baik dengan cara mengenali folikel yang menempel. Beberapa penelitian sebelumnya metode komputasi menghasilkan segmentasi yang berlebihan sehingga ada kesalahan jumlah folikel yang menempel. Penelitian ini akan membantu dokter untuk perhitungan otomatis jumlah folikel pada gambar ultrasonografi ovarium, penelitian ini membandingkan metode segmentasi untuk mengenali folikel pada citra ultrasonografi ovarium, metode segmentasi yang paling baik akan digunakan untuk proses perhitungan jumlah folikel. Metode segmentasi yang digunakan active contour dan active contour without edge. Kinerja model segmentasi akan diuji pada dataset citra ultrasonografi ovarium pada pasien RSU Sakina Idaman Yogyakarta.

\section{TINJAUAN PUSTAKA}

Segmentasi merupakan proses membagi citra menjadi beberapa wilayah yang memiliki tampilan visual yang cukup homogen atau yang sesuai dengan objek atau bagian objek [5]. Segmentasi citra bertujuan mengambil informasi yang terdapat di dalam suatu citra, membagi suatu citra ke dalam sejumlah area atau objek. Idealnya, langkah segmentasi tersebut dihentikan pada saat objek yang diinginkan sudah berhasil dipisahkan. Algoritma segmentasi untuk citra monochrome biasanya berdasarkan pada satu dari dua sifat nilai gray level yaitu diskontinuitas dan similaritas. Diskontinuitas, pendekatan yang dilakukan adalah memisahkan citra berdasarkan terjadinya perubahan nilai gray level yang drastis. Sedangkan pada similaritas, pendekatan dilakukan berdasarkan thresholding, region growing, region spitting dan merging [6]. Secara umum metode segmentasi dapat dikelompokkan menjadi empat yakni : 1) thresholding, 2) shapebased, 3) region growing, dan 4) clustering [5]-[9].

Kajian pustaka segmentasi gambar ultrasonografi ovarium, salah satunya metode segmentasi dengan region growing, [10] 
melakukan dalam tiga tahapan yaitu identifikasi homogeneous region, region growing dan ekstraksi folikel. Identifikasi homogeneous region dicapai dengan menggunakan adaptive neighborhood median memfilter noise pada gambar ultrasonografi ovarium. Identifikasi homogeneous region dianggap sebagai perkiraan dari folikel dan region growing digunakan memperluas perkiraan ke batas folikel sebenarnya. Proses berulang menumbuhkan setiap wilayah homogen. Proses iteratif, pixel individual digabung dengan wilayah homogen jika memenuhi dua penggabungan kriteria. Kedua kriteria didasarkan pada intensitas piksel individual dan bobot gradien. Daerah diidentifikasi dalam upaya untuk menghapus wilayah yang tidak sesuai dengan folikel sebenarnya.

Metode segmentasi region growing yang dilakukan [10] menggabungan beberapa pixel dengan thresholding memiliki kondisi konektivitas atau kriteria daerah homogenitas, tetapi hanya dapat bekerja dengan baik pada daerah homogen serta membutuhkan operator untuk menentukan daerah akan tersegmentasi. Segmentasi folikel menggunakan deteksi tepi dengan metode Canny telah dilakukan [11]. Deteksi tepi Canny merupakan algoritma pendeteksi tepi dapat mendeteksi tepi menggunakan kriteria-kriteria sesuai keinginan agar hasil optimal, langkah deteksi tepi Canny adalah komputasi gradien pada sumbu $\mathrm{x}$ dan $\mathrm{y}$, komputasi magnitude dan orientasi gradien, selanjutnya non maximum supression, kalkulasi threshold tinggi dan rendah serta hysteresis thresholding. [11] menghilangkan noise yang ada pada citra menggunakan filter gaussian. Hasil citra tampak sedikit buram mendapatkan tepi citra sebenarnya. Langkah selanjutnya menemukan edge strength dengan cara mencari gradien citra. Metode Sobel menggunakan pendekatan 2D spatial gradien, sehingga absolute magnitude gradient (edge strength) dapat ditemukan. Menentukan arah tepian (edge direction) digunakan untuk menghubungkan dengan arah dari piksel citra. Menerapkan nonmaximum suppression denghsn maxima local saja yang ditandai sebagai tepian, langkah ini bertujuan untuk mengkonversi tepian yang masih blur dari hasil magnitude gradient sehingga menghasilkan tepian yang tajam. Canny menggunakan thresholding ganda dimana tepian nilai yang lebih besar dari thresholding atas (high thresholding) ditandai sebagai titik kuat, tepian dengan nilai yang lebih kecil dari thresholding bawah (low thresholding) akan dihapus, dan tepian dengan nilai piksel antara thresholding atas dengan thresholding bawah akan ditandai sebagai tepian yang lemah.

Metode segmentasi citra ultrasonografi ovarium dengan watershed [12] menghasilkan segmentasi yang berlebihan sehingga ada folikel yang menempel tidak terdeteksi dengan baik, menyelesaikan masalah segmentasi yang 
berlebihan dapat dilakukan pemrosesan awal mengurangi noise dengan contourlet transform, sedangkan [13] pada pemrosesan awal melakukan histogram equalization serta negative transformation, hasil deteksi terdapat folikel ukuran kecil tidak dikenali.

Menurut Hiremart dan Tegnor, metode thresholding yang optimal untuk citra ultrasonografi ovarium yang dilakukan [10] dengan estimasi batas ovarium tidak menghasilkan hasil yang efektif [13].

Yinhui Deng dan Ping Chen mengembangkan metode region growing untuk deteksi folikel tetapi membutuhkan titik yang dipilih secara manual oleh dokter [12]. Palak Mehrotra dan Chandan Chakraborty menggunakan morfologi open dan operasi close, mengekstrak ciri dari citra USG dengan menggunakan tophat transform dan scanline thresholding untuk menyegmentasikan citra ultrasonografi ovarium untuk mengurangi tingkat kesalahan dengan deteksi manual [14].

Segmentasi citra ultrasonografi ovarium menggunakan scanline threshold dan menggunakan ciri geometrik dilakukan oleh [15], segmentasi citra ultrasonografi ovarium menggunakan scanline threshold dengan 30 data input gambar ultrasonografi ovarium dengan pengukuran kesalahan menggunakan mean square error telah dilakukan [14], sedangkan [16] segmentasi citra ultrasonografi ovarium untuk mengenali kista menggunakan scanline threshold dengan 25 data input gambar ultrasonografi ovarium. Segmentasi pada citra ultrasonografi ovarium telah dilakukan [17] dengan menggunakan modifikasi otsu thresholding.

\subsection{Active Contour}

Active contour (AC) mengembangkan sebuah kurva membentuk suatu contour yang merupakan tepian suatu obyek dalam citra tersebut. Kurva awal dibuat sebagai acuan pengembangan kurva berikutnya. Misalnya dimulai dengan kurva di sekitar objek yang akan dideteksi, kurva bergerak ke arah dalam dan ke arah luar di bawah batas dari citra dan harus berhenti pada batas tepi obyek. Semua model active contour, deteksi tepi digunakan untuk menghentikan perkembangan kurva pada batasbatas objek yang diinginkan. Biasanya adalah fungsi tepi positif dan regular $g\left(\left|\nabla U_{0}\right|\right)$ ditunjukkan oleh Persamaan (1), diturunkan menjadi $\lim _{t \rightarrow g(t)}=0$.

$$
g\left(\left|\nabla U_{0}\right|\right)=\frac{1}{1+\left|\nabla G_{\sigma} * U_{0}\right|^{2}}
$$

Dimana $G_{\sigma} * U_{0}$ adalah konvolusi dari citra $U_{0}$ dengan Gaussian $G_{\sigma}(x, y)=$ $\sigma^{-\frac{1}{2}} \exp \left(\frac{\left|x^{2}+y^{2}\right|}{4 \sigma}\right)$. Suatu fungsi $g\left(\left|\nabla U_{0}\right|\right)$ akan selalu positif diwilayah homogen, dan mendekati nol pada tepian kurva. Perkembangan kurva dengan variasi dari rata-rata pergerakan kelengkungan dengan fungsi tepi $g\left(\left|\nabla U_{0}\right|\right)$ 
sebagai faktor tambahan dalam kecepatan. Untuk persamaan energi ekstenal ditunjukkan oleh Persamaan (2), untuk menghitung fungsi jarak maka gunakan perhitungan energi internal seperti pada Persamaan (3).

$$
\begin{gathered}
\varepsilon_{g, \lambda, v}(\phi)=\lambda \cdot L_{g}(\phi)+V \cdot A_{g}(\phi) \\
\varepsilon(\phi)=\mu . P(\phi)+\varepsilon_{m}(\phi)
\end{gathered}
$$

Semua model snake klasik atau model active contour bergantung pada fungsi tepi $g$ ini, tergantung pada gradien citra $\left|\nabla U_{0}\right|$, untuk menghentikan evolusi kurva. Oleh karena itu, model ini hanya dapat mendeteksi obyek dengan tepi yang didefinisikan oleh gradien. Dalam pelatihan gradien diskrit dibatasi dan kemudian menghentikan fungsi $g$ tidak pernah nol di tepi, dan kurva dapat melewati tepian. Di sisi lain, jika citra $U_{0}$ noise maka penghalusan menggunakan gaussian harus kuat yang akan memperhalus tepi [18].

\subsection{Active Contour Without Edge}

Active Contour Without Edge (ACWE) merupakan metode segmentasi citra yang dikembangkan oleh Chan dan Vese, sebagai salah satu modifikasi dari segmentasi active Contour [19], [20]. Metode active contour konvensional menggunakan konsep gradien tepi untuk menemukan objeknya sehingga membutuhkan energi yang cukup besar proses segmentasi dan menggunakan tepian objek yang didefinisikan oleh gradien gambar untuk menghentikan iterasi. Hal ini dinilai kuirang efektif oleh Chan dan Vese. Beberapa kasus gambar seperti gambar berkontras rendah, objek bervariasi, objek dengan beda intensitas, kontur yang halus dan noise yang tinggi juga masih belum bisa disegmentasi dengan baik oleh active contour, oleh karena itu dikembangkan metode untuk meminimalkan energi yang dibutuhkan dan tidak bergantung pada gradien citra. Pada dasarnya ACWE melakukan perbandingan antara total nilai dari inside energy dan outside energy.

Inside energy adalah total kuadrat dari selisih setiap piksel yang tersebar di dalam area kurva dengan rata-rata piksel yang berada dalam area kurva $\left(C_{1}\right)$. Outside energy adalah total kuadrat setiap piksel yang tersebar di luar area kurva $\left(C_{2}\right)$ dimana $u_{0}(x, y)$ merepresentasikan nilai piksel pada citra $f(x, y) . C$ merupakan variabel dari kurva dimana nilai $C_{1}$ dan $C_{2}$ bergantung pada lokasi piksel terhadapa kurva $C$ di dalam citra $u_{0}$. Algoritma active contour without edge pada penelitian ini dapat dilihat urutannya sebagai berikut :

1. Inisialisasi area mask dianggap sebagai area objek awal (inside index) sedangkan di luar dianggap sebagai area background (outside index) dengan bentuk persegi.

2. Hitung nilai Euclidean Distance (ED) setiap piksel terhadap mask dan negatif mask. Konsep euclidean distance adalah mencari jarak dari suatu titik $\left(x_{1}, y_{1}\right)$ terhadap 
$\left(x_{2}, y_{2}\right)$

$$
E D=\sqrt{\left(x_{1}-x_{2}\right)^{2}+\left(y_{1}-y_{2}\right)^{2}}
$$

\section{Keterangan}

$x_{1}=$ Koordinat piksel $x$ pada titik a

$y_{1}=$ Koordinat piksel $y$ pada titik a

$x_{2}=$ Koordinat piksel $x$ pada titik $\mathrm{b}$

$y_{2}=$ Koordinat piksel $y$ pada titik b

3. Gunakan level set method formula untuk mendapatkan batas-batas antara area di luar kurva dan area di dalam kurva $C$.

$$
C \subset \Omega\left\{\begin{array}{c}
C=\partial \omega=\{(x, y) \in \Omega: \phi(x, y)=0\}, \\
\text { inside }(C)=\omega=\{(x, y) \in \Omega: \phi(x, y)>0\}, \\
\text { outside }(C)=\frac{\Omega}{\bar{\omega}}=\{(x, y) \in \Omega: \phi(x, y)<0\},
\end{array}\right.
$$

nilai phi $(\phi)$ diterapkan dalam level set method untuk mendapatkan inside index dan outside index. $\Omega$ merupakan citra dimana $C \subset \Omega, \omega \subset \Omega, C \subset \partial \omega$ merepresentasikan area objek sehingga didapatkan inside ( $C$ ) adalah area $\omega$, sedangkan outside $(C)$ adalah area $\frac{\Omega}{\bar{\omega}}$. Area inside adalah area ketika nilai $\phi>0$ dan outside adalah area ketika nilai $\phi<0$.

4. Hitung bentuk komplemen nilai piksel $u_{0}(x, y)$ dengan Persamaan (6).

$$
u_{0}(x, y)^{c}=255-u_{0}(x, y)
$$

5. Ubah variabel $C$ ke variabel $\phi$ dengan menggunakan fungsi heaviside $H$ dan fungsi dirac satu dimensi menjadi Persamaan (7).

$$
\begin{gathered}
(\phi(x, y))\left\{\begin{array}{l}
1, \text { jika } \phi>\varepsilon \\
0, \text { jika } \phi<\varepsilon
\end{array}\right. \\
\delta(\phi)=\frac{d}{d z} H(\phi)=\frac{\varepsilon}{\pi\left(\varepsilon^{2}+\phi^{2}\right)}
\end{gathered}
$$

6. Hitung nilai $C_{1}$ berdasarkan pembagian nilai pembagian nilai perkalian piksel komplemen piksel terhadap fungsi heaviside (area dalam kurva).

$$
\begin{gathered}
C_{1}=\frac{\operatorname{sum}(\operatorname{inside}(C))}{\text { length }(\operatorname{inside}(C))} \\
C_{1}=\frac{\left(\sum u_{0}(x, y)^{c}\right)(H(\phi(x, y)))}{\sum u_{0}((x, y) \in \Omega: \phi(x, y) \geq 0)^{c}}
\end{gathered}
$$

7. Hitung nilai $C_{2}$ melalui pembagian nilai perkalian piksel komplemen piksel terhadap fungsi inversi heaviside (area luar kurva).

$$
C_{2}=\frac{\operatorname{sum}(\text { outside }(C))}{\text { length }(\text { outside }(C))}
$$

$$
C_{2}=\frac{\left(\sum u_{0}(x, y)^{c}\right)(1-H(\phi(x, y)))}{\sum u_{0}((x, y) \in \Omega: \phi(x, y)<0)^{c}}
$$

8. Posisi dan area dari kurva / mask tersebut akan mengembangkan atau mengerucut sesuai dengan fungsi energi tiap piksel $F\left(C_{1}, C_{2}, C\right)$ yang sudah diubah dengan fungsi heaviside dan diract.

$$
\begin{gathered}
F\left(C_{1}, C_{2}, C\right)=F\left(C_{1}, C_{2}, \phi\right) \\
=\mu \int_{\Omega} \delta(\phi(x, y))|\nabla \phi(x, y)| d x d y \\
+v \int_{\Omega} H(\phi(x, y)) \\
+\lambda_{1} \int_{\Omega}\left|u_{0}(x, y)-c_{1}\right|^{2} H(\phi(x, y)) d x d y \\
+\lambda_{2} \int_{\Omega}\left|u_{0}(x, y)-c_{2}\right|^{2}(1-H(\phi(x, y))) d x d y
\end{gathered}
$$


9. Konstanta variabel pelebaran atau pengerucutan kurva melibatkan $H(\phi(x, y))$ dengan nilai adalah $\varepsilon$ dan $10^{-5}$.

$$
H(\phi)\left\{\begin{array}{c}
1, j i k a \phi>\varepsilon \\
0, j i k a \phi \varepsilon, \\
\frac{1}{2}\left[1+\frac{\phi}{\varepsilon}+\frac{1}{\pi} \sin \left(\frac{\pi \phi}{\varepsilon}\right)\right], j i k a|\phi| \leq \varepsilon
\end{array}\right.
$$

10. Hitung nilai kappa, yakni informasi perbedaan ketetanggann setiap nilai piksel berdasarkan $\phi$ dari citra $f(x, y)$.

$$
\begin{gathered}
\operatorname{Kappa}(\phi)=\frac{K G}{\max (K \cdot G)} \\
K=\frac{f x x \cdot f y^{2}-2 f x y \cdot f x \cdot f y \cdot f y y+f y y \cdot f x^{2}}{f y^{2}+f y^{2}+\varepsilon^{1.5}} \\
G=\sqrt{f x^{2}+f y^{2}} \\
f x=f(x+1, y)-f(x-1, y) \\
f y=f(x, y+1)-f(x, y-1) \\
f x x=f(x+1, y)+f(x-1, y)-2 f(x, y) \\
f y y=f(x, y+1)+f(x, y-1)-2 f(x, y) \\
f x y=f(x+1, y-1)-f(x+1, y+1) \\
+f(x-1, y-1)-f(x-1, y \\
+1)
\end{gathered}
$$

11. Hitung total energi citra pada setiap iterasi. Variabel $\mu$ adalah konstanta dengan nilai 0.2.

$$
\begin{aligned}
F(x, y)= & \frac{\mu \cdot \operatorname{Kappa}(\phi)}{\max (\operatorname{Kappa}(\phi))} \\
& +\left(F\left(C_{1}, C_{2}, C\right)\right)
\end{aligned}
$$

12. Normalisasi total energi dengan membagi nilai total energi maksimum absolut total energi.

$$
F(x, y)=\frac{F(x, y)}{\max (|F(x, y)|)}
$$

13. Nilai kurva lama $\left(\phi_{0}\right)$ akan diperbaharui dengan mengalikan nilai $d t$ dengan energi $(F(x, y))$. Hasil perkalian tersebut kemudian ditambahkan dengan nilai $\phi_{0}$ sehingga menghasilkan $\phi_{1}$ seperti persamaan dibawah ini. Besaran konstanta yang digunakan adalah 0.5 .

$$
\phi_{1}(x, y)=\phi_{0}(x, y)+d t . F(x, y)
$$

Jika nilai kurva lama $\left(\phi_{0}\right)$ dengan nilai kurva yang baru $\left(\phi_{1}\right)$ sama maka iterasi akan berhenti dan mendapatkan hasil segmentasi. Namun apabila kedua nilai tersebut masih berbeda atau berasa diatas batas toleransi perbedaan nilai $\left(\phi_{0}\right)$ dan $\left(\phi_{1}\right)$, maka akan dilakukan perhitungan energi pada kurva yang baru. Proses perhitungan akan terus dilakukan hingga nilai sama untuk $\left(\phi_{0}\right)$ dan $\left(\phi_{1}\right)$, atau nilai energi sudah mendekati nilai 0 . Nilai toleransi batas perbedaan $\left(\phi_{0}\right)$ dan $\left(\phi_{1}\right)$ adalah 0.0162 . Kondisi berhenti lainnya apabila iterasi maksimum yang ditentukan telah tercapai [19].

\subsection{Pengujian Hasil segmentasi}

Pengujian metode segmentasi berdasarkan nilai Probabilistic Rand Index (PRI) dan Global Consistency Error (GCE) untuk mengevaluasi 
Volume 16 Nomor 1 (2021) 14-27

E - Link P-ISSN 1858-2109 E-ISSN 2656-5676

Jurnal Teknik Elektro dan Informatika

kinerja metode active contour dan active contour without edge.

Probabilistic Rand Index (PRI) merupakan indeks rand adalah fungsi yang mengubah membandingkan dua partisi dengan jumlah kelas yang mungkin berbeda. Formula untuk PRI didefinisikan dalam Persamaan (24).

$$
P R\left(R_{\text {test }},\left\{R_{G T}\right\}\right)=\frac{1}{\left(\begin{array}{c}
n \\
2
\end{array}\right)} \sum_{\substack{i, j \\
i<j}}\left[c_{i j} p_{i j}+\left(1-c_{i j}\right)\left(1-p_{i j}\right)\right]
$$

dimana $\mathrm{R}_{\mathrm{GT}}$ adalah gambar ground truth yang dikelompokkan secara manual $\left\{R_{1}\right.$, $\left.\mathrm{R}_{2}, \ldots . \mathrm{R}_{\mathrm{GT}}\right\}$ \}sesuai dengan gambar ovarium tersegmentasi $\mathrm{Y}=\left\{\mathrm{Y}_{1}, \mathrm{Y}_{2}, . ., \mathrm{Y}_{\mathrm{n}}\right\}$ oleh algoritma. Himpunan semua segmentasi yang benar secara persepsi didefinisikan oleh angka acak $\mathrm{p}_{\mathrm{ij}}$, $\mathrm{C}_{\mathrm{ij}}$ menunjukkan peristiwa sepasang piksel ' $\mathrm{i}$ ' dan 'j' memiliki label yang sama pada gambar uji $R_{\text {test. }}$

$$
c_{i j}=I\left(L_{i}^{R_{\text {test }}}=L_{j}^{R_{\text {test }}}\right)
$$

Global Consistency Error (GCE) adalah ukuran untuk menilai sejauh mana hasil segmentasi. GCE digunakan sebagai ukuran untuk bandingkan hasil dari metode segmentasi yang diusulkan $\left(\mathrm{I}_{1}\right)$ ) untuk ground Truth $\left(\mathrm{I}_{2}\right)$. Piksel $p_{a}$, pada gambar tersegmentasi $I_{1}$ dan $I_{2}$ untuk ground truth, ukuran GCE menghasilkan output bernilai nyata dalam kisaran [0: 1], di mana nol menandakan tidak ada kesalahan.

$$
G C E=\frac{I}{N} \min \left\{\sum a P_{a}\left(I_{1}, I_{2}\right), \sum a P_{a}\left(I_{2}, I_{1}\right)\right\}
$$

\section{METODOLOGI PENELITIAN}

Metodologi penelitian yang dilakukan ditunjukkan pada Gambar 1 yang menguraikan urutan langkah yang dilakukan untuk mendapatkan metode segmentasi terbaik.

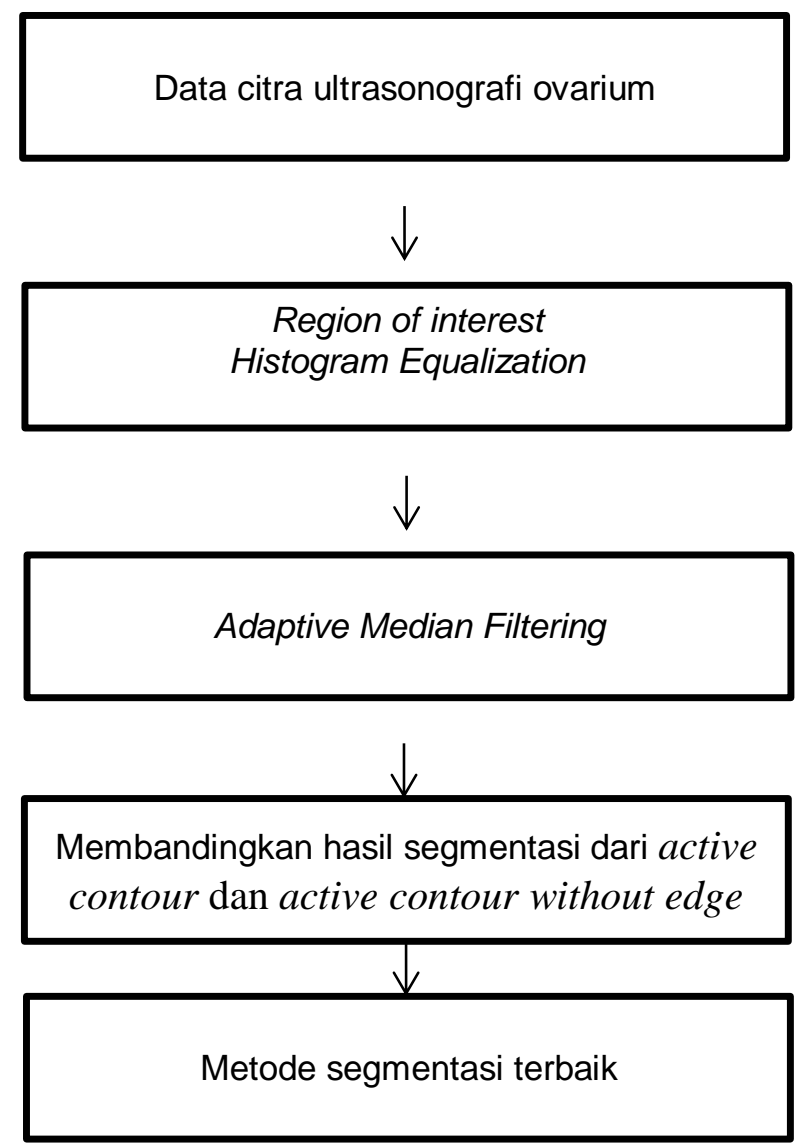

Gambar 1. Blok Diagram Pemilihan Metode Segmentasi Terbaik

Citra ultrasonografi ovarium terdapat speckle noise, maka untuk mengurangi speckle noise akan dilakukan adaptive median filtering. Adaptive median filtering dapat menangani operasi filter pada gambar rusak dengan impuls noise. Adaptive median filtering memperhalus noise, memberikan output citra jauh lebih baik dari standar median filtering. Langkah awal 
menentukan nilai maksimum, minimum dan median untuk masing-masing ukuran window, sehinggga menghasilkan matrik maksimum $\left(Z_{\text {max }}\right)$, matrik minimum $\left(Z_{\text {min }}\right)$, matrik median $\left(Z_{\text {median }}\right)$. Adaptive median filter bekerja pada 2 level yaitu [6].

Penelitian ini menggunakan metode segmentasi active contour, active contour without edge dan watershed. Hasil segmentasi akan dibandingkan menggunakan probabilistic rand index dan global consistency.

\section{HASIL PENELITIAN}

Contoh citra ultrasonografi ovarium ditunjukkan pada Gambar 2 yang akan digunakan untuk analisis mendapatkan metode segmentasi yang terbaik.

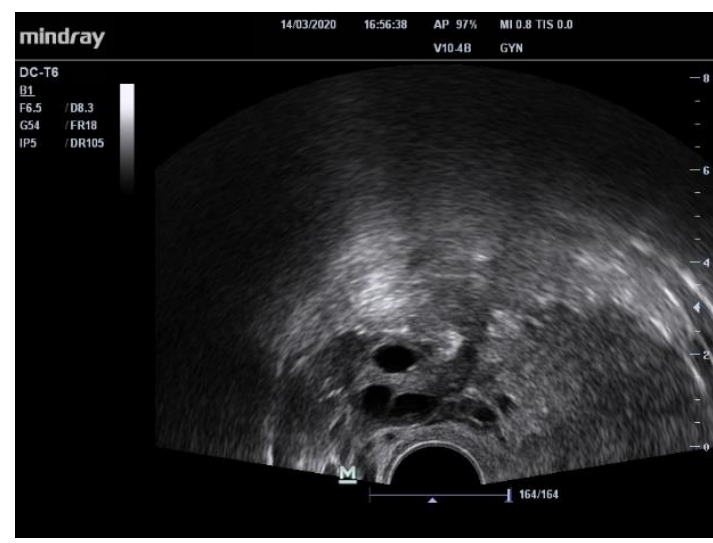

Gambar 2. Citra Ultrasonografi Ovarium

Gambar 3 menampilkan hasil penelitian dengan langkah awal akusisi citra asli, selanjutnya melakukan pemilihan region of interest dengan cara cropping citra yang dibutuhkan, untuk mengetahui gambaran penyebaran nilai-nilai intensitas pixel dari citra ultrasonografi ovarium maka dilakukan proses histogram equalization, langkah selanjutnya melakukan filtering untuk mengurangi noise pada citra ultrasonografi ovarium menggunakan Adaptive Median Filtering (AMF).

Penilaian kinerja active contour dan active contour without edge dievaluasi menggunakan Probabilistic Rand Index (PRI) dan Global Consistency Error (GCE). Setiap data citra uji akan dibandingkan nilai PRI dan GCE dari metode active contour dan active contour without edge. Metode segmentasi yang terbaik adalah metode yang memiliki nilai PRI lebih tinggi dari 50\% keseluruhan data dan nilai GCE lebih rendah dari $50 \%$ keseluruhan data.

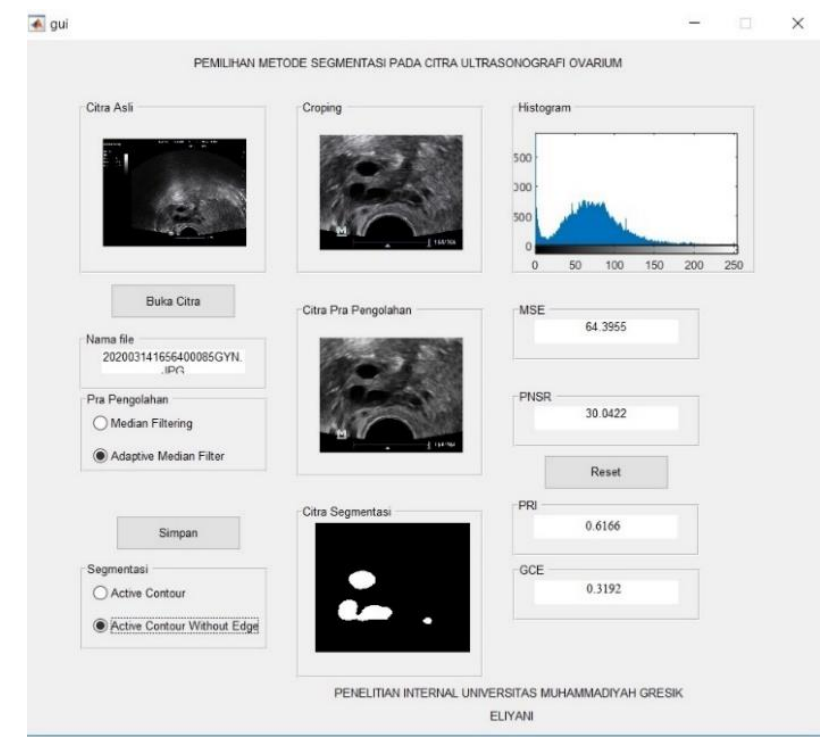

Gambar 3. Analisis Citra Ultrasonografi Ovarium.

Tabel 1 nilai Probabilistic Rand Index dan Global Consistency Error untuk 20 citra uji menggunakan active contour. 
Tabel 1. Kinerja metode segmentasi active contour

\begin{tabular}{lll}
\hline \multicolumn{1}{c}{ Data } & PRI & GCE \\
\hline Citrauji1 & 0.5712 & 0.4635 \\
Citrauji2 & 0.3221 & 0.2785 \\
Citrauji3 & 0.4111 & 0.3761 \\
Citrauji4 & 0.6151 & 0.5422 \\
Citrauji5 & 0.2014 & 0.1482 \\
Citrauji6 & 0.2615 & 0.1498 \\
Citrauji7 & 0.4028 & 0.3853 \\
Citrauji8 & 0.3514 & 0.2334 \\
Citrauji9 & 0.8113 & 0.7937 \\
Citrauji10 & 0.1517 & 0.0104 \\
Citrauji11 & 0.6325 & 0.5675 \\
Citrauji12 & 0.2413 & 0.1536 \\
Citrauji13 & 0.5219 & 0.4785 \\
Citrauji14 & 0.1125 & 0.0173 \\
Citrauji15 & 0.3826 & 0.1136 \\
Citrauji16 & 0.7215 & 0.5873 \\
Citrauji17 & 0.2614 & 0.0701 \\
Citrauji18 & 0.8216 & 0.7874 \\
Citrauji19 & 0.3713 & 0.1125 \\
Citrauji20 & 0.3218 & 0.2197 \\
\hline & & \\
\hline
\end{tabular}

Tabel 2 nilai Probabilistic Rand Index (PRI) dan Global Consistency Error untuk 20 citra uji menggunakan active contour without edge. Tabel 2 hasil segmentasi active contour without edge nilai PRI lebih tinggi dari nilai GCE untuk setiap citra uji.
Tabel 2. Kinerja metode segmentasi active contour without edge.

\begin{tabular}{cll}
\hline Data & PRI & GCE \\
\hline Citrauji1 & 0.6166 & 0.3192 \\
Citrauji2 & 0.4651 & 0.1248 \\
Citrauji3 & 0.5368 & 0.2191 \\
Citrauji4 & 0.7037 & 0.4373 \\
Citrauji5 & 0.3372 & 0.1294 \\
Citrauji6 & 0.4759 & 0.2137 \\
Citrauji7 & 0.5113 & 0.3427 \\
Citrauji8 & 0.4827 & 0.2214 \\
Citrauji9 & 0.9282 & 0.6119 \\
Citrauji10 & 0.2697 & 0.1002 \\
Citrauji11 & 0.7828 & 0.5219 \\
Citrauji12 & 0.3252 & 0.1128 \\
Citrauji13 & 0.6923 & 0.6337 \\
Citrauji14 & 0.5868 & 0.0142 \\
Citrauji15 & 0.4274 & 0.2192 \\
Citrauji16 & 0.8186 & 0.5283 \\
Citrauji17 & 0.3538 & 0.1108 \\
Citrauji18 & 0.9892 & 0.1293 \\
Citrauji19 & 0.2124 & 0.0192 \\
Citrauji20 & 0.4985 & 0.1126 \\
\hline & & \\
\hline
\end{tabular}

Tabel 3 nilai Probabilistic Rand Index (PRI) untuk citra uji menggunakan active contour mendapatkan nilai tertinggi pada 1 citra uji atau 5\% dari keseluruhan data, sedangkan active contour without edge memiliki nilai PRI tertinggi pada 19 citra uji atau 95\% dari keseluruhan data. Penelitian ini menunjukkan 
Volume 16 Nomor 1 (2021) 14-27

E - Link P-ISSN 1858-2109 E-ISSN 2656-5676

Jurnal Teknik Elektro dan Informatika

metode active contour without edge

$\begin{array}{llll}\text { Citrauji20 } & 0.3218 & 0.4985 & \text { ACWE }\end{array}$

mendapatkan rata-rata tertinggi nilai PRI dari

Rata-rata

$0.424 \quad 0.55071$

keseluruhan data. Rata-rata nilai PRI lebih tinggi active contour without edge dari pada active contour yaitu 0.55071 . Kinerja active contour without edge lebih baik berdasarkan nilai PRI yang dihasilkan lebih tinggi dari pada active contour.

Tabel 3. Nilai Probabilistic Rand Index

\begin{tabular}{|c|c|c|c|}
\hline Data & $\begin{array}{l}\text { Active } \\
\text { contour }\end{array}$ & $\begin{array}{l}\text { Active } \\
\text { contour } \\
\text { without } \\
\text { egde }\end{array}$ & $\begin{array}{c}\text { PRI } \\
\text { Tertinggi }\end{array}$ \\
\hline Citrauji1 & 0.5712 & 0.6166 & ACWE \\
\hline Citrauji2 & 0.3221 & 0.4651 & ACWE \\
\hline Citrauji3 & 0.4111 & 0.5368 & ACWE \\
\hline Citrauji4 & 0.6151 & 0.7037 & ACWE \\
\hline Citrauji5 & 0.2014 & 0.3372 & ACWE \\
\hline Citrauji6 & 0.2615 & 0.4759 & ACWE \\
\hline Citrauji7 & 0.4028 & 0.5113 & ACWE \\
\hline Citrauji8 & 0.3514 & 0.4827 & ACWE \\
\hline Citrauji9 & 0.8113 & 0.9282 & ACWE \\
\hline Citrauji10 & 0.1517 & 0.2697 & ACWE \\
\hline Citrauji11 & 0.6325 & 0.7828 & ACWE \\
\hline Citrauji12 & 0.2413 & 0.3252 & ACWE \\
\hline Citrauji13 & 0.5219 & 0.6923 & ACWE \\
\hline Citrauji14 & 0.1125 & 0.5868 & ACWE \\
\hline Citrauji15 & 0.3826 & 0.4274 & ACWE \\
\hline Citrauji16 & 0.7215 & 0.8186 & ACWE \\
\hline Citrauji17 & 0.2614 & 0.3538 & ACWE \\
\hline Citrauji18 & 0.8216 & 0.9892 & ACWE \\
\hline Citrauji19 & 0.3713 & 0.2124 & $\mathrm{AC}$ \\
\hline
\end{tabular}

Gambar 4 diagram nilai Probabilistic Rand Index (PRI) untuk seluruh citra uji menggunakan active contour dan active contour without edge.

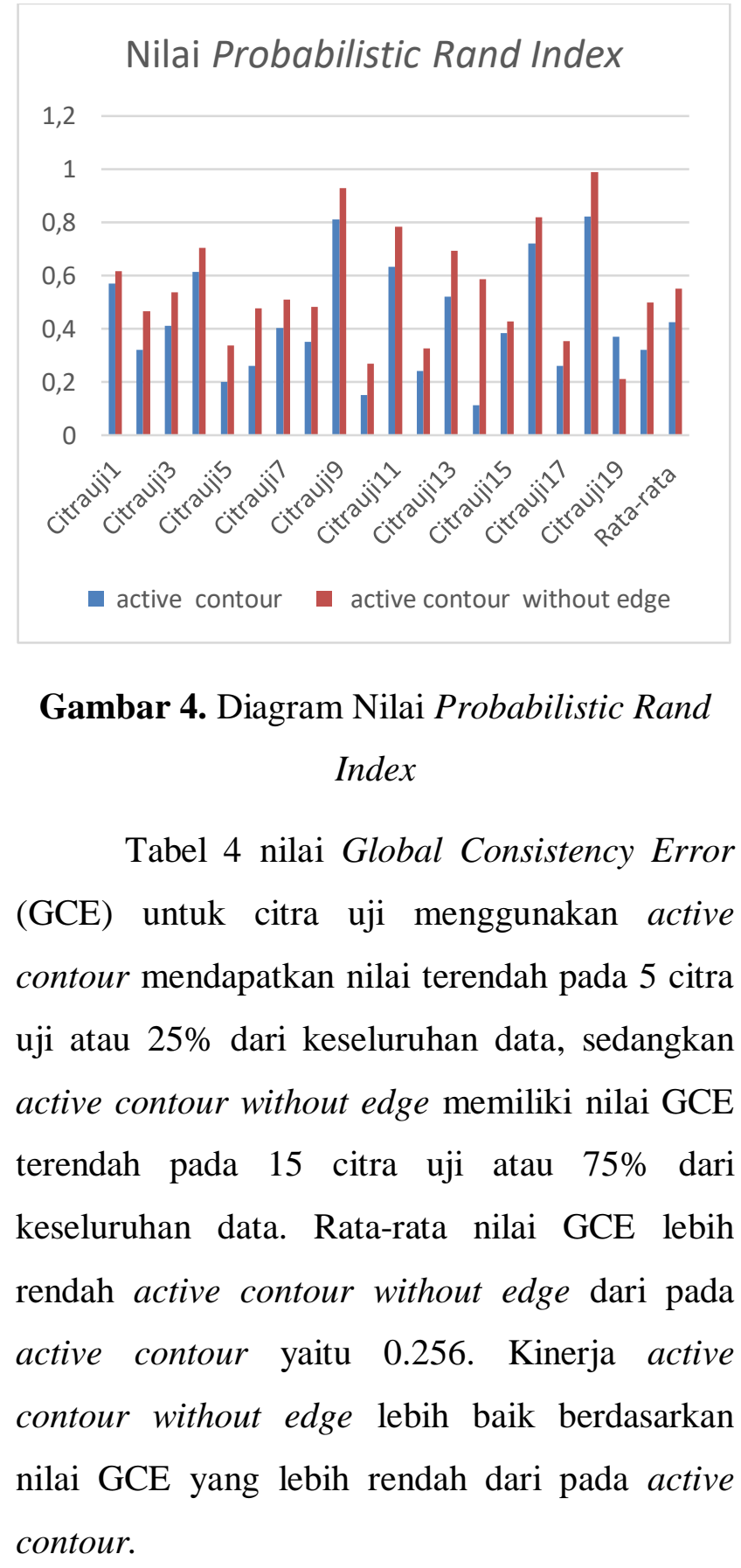


Tabel 4. Nilai Global Consistency Error

\begin{tabular}{lrrr}
\hline \multicolumn{1}{c}{ Data } & Active & Active & \multicolumn{1}{c}{ GCE } \\
& contour & $\begin{array}{r}\text { contour } \\
\text { without } \\
\text { Terendah }\end{array}$ \\
& & \\
& & \\
& & \\
Citrauji1 & 0.4635 & 0.3192 & ACWE \\
Citrauji2 & 0.2785 & 0.1248 & ACWE \\
Citrauji3 & 0.3761 & 0.2191 & ACWE \\
Citrauji4 & 0.5422 & 0.4373 & ACWE \\
Citrauji5 & 0.1482 & 0.1294 & ACWE \\
Citrauji6 & 0.1498 & 0.2137 & AC \\
Citrauji7 & 0.3853 & 0.3427 & ACWE \\
Citrauji8 & 0.2334 & 0.2214 & ACWE \\
Citrauji9 & 0.7937 & 0.6119 & ACWE \\
Citrauji10 & 0.0104 & 0.1002 & AC \\
Citrauji11 & 0.5675 & 0.5219 & ACWE \\
Citrauji12 & 0.1536 & 0.1128 & ACWE \\
Citrauji13 & 0.4785 & 0.6337 & AC \\
Citrauji14 & 0.0173 & 0.0142 & ACWE \\
Citrauji15 & 0.1136 & 0.2192 & AC \\
Citrauji16 & 0.5873 & 0.5283 & ACWE \\
Citrauji17 & 0.0701 & 0.1108 & AC \\
Citrauji18 & 0.7874 & 0.1293 & ACWE \\
Citrauji19 & 0.1125 & 0.0192 & ACWE \\
Citrauji20 & 0.2197 & 0.1126 & ACWE \\
\hline Rata-rata & 0.324 & 0.256 & \\
\hline
\end{tabular}

Gambar 5 menunjukkan diagram nilai Global Consistency Error untuk seluruh citra uji menggunakan active contour dan active contour without edge.

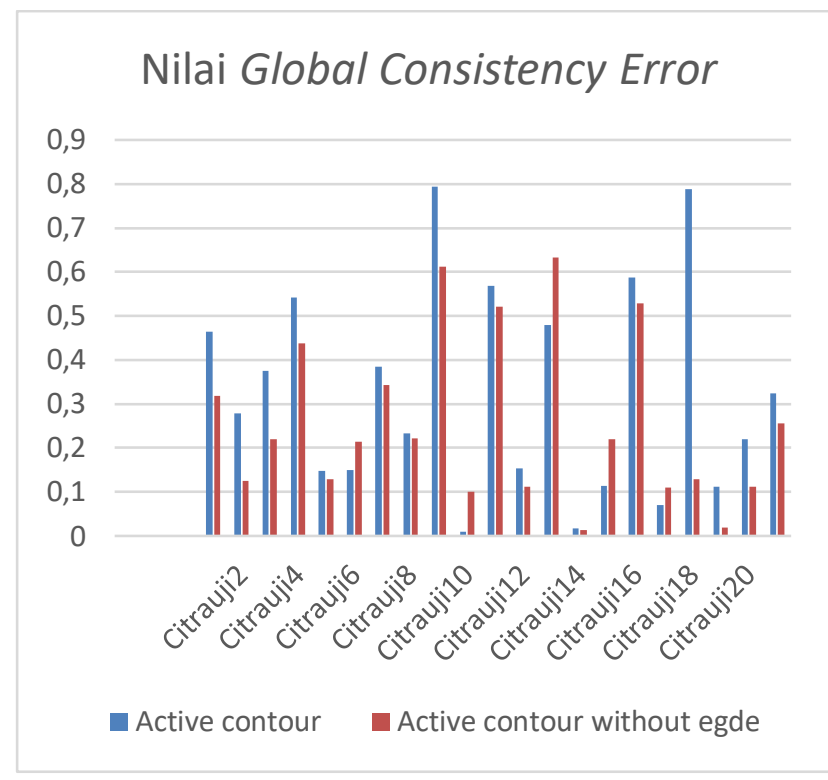

Gambar 5. Diagram Nilai Global Consistency

\section{Error}

\section{KESIMPULAN}

Active contour membagi citra USG ovarium ke dalam beberapa daerah dan memisahkankan daerah objek dan latar belakang dari USG ovarium. Active contour memiliki kekurangan yaitu tidak mengenali folikel ukuran kecil. Active contour without edge dapat mengenali folikel ukuran kecil. Penilaian kinerja metode segmentasi active contour dan active contour without edge dievaluasi menggunakan Probabilistic Rand Index (PRI) dan Global Consistency Error (GCE). Metode segmentasi yang terbaik adalah active contour without edge karena memiliki nilai PRI lebih tinggi dari pada active contour, serta active contour without edge 
menghasilkan nilai GCE lebih rendah dari pada active contour.

\section{DAFTAR PUSTAKA}

[1] Center for Disease Control and Prevention, "Infertility," Natl. Cent. Heal. Stat., vol. July 15, 2016.

[2] Syamsiah, "Kesehatan Reproduksi," Yogyakarta, 2010.

[3] Badan Penelitian dan Pengembangan Kesehatan Kementerian RI, "Riset Kesehatan Dasar,” 2013.

[4] S. Kushwaha, "An Efficient Filtering Approach for Speckle Reduction in Ultrasound Images," vol. 10, no. 3, hal. 1355-1367, 2017.

[5] A. K. Jain, Fundamentals of Digital Image Processing. New Jersey, USA: Prentice-Hall International Editions, 1989.

[6] R. C. . Gonzalez dan R. E. Woods, "Digital image processing," Nueva Jersey. hal. 976, 2008.

[7] C. Solomon dan T. Breckon, Fundamentals of Digital Image Processing, 3rd ed., V. New Jersey: Wiley-Blackwell, 2011.

[8] J. Zhang, K.-K. Ma, M.-H. Er, dan V. Chong, "Tumor Segmentation from Magnetic Resonance Imaging by Learning via one-class support vector machine," Int.
Work. Adv. Image Technol. (IWAIT '04), hal. 207-211, 2004.

[9] S. Shen dan W. Sandham, "MRI Fuzzy Segmentation of Brain Tissue Using Neighborhood Attraction With," IEEE Trans. Inf. Technol. Biomed., vol. 9, no. 3, hal. 459-467, 2005.

[10] B. Potočnik dan D. Zazula, "Automated analysis of a sequence of ovarian ultrasound images. Part I: Segmentation of single 2D images," Image Vis. Comput., vol. 20, no. 3, hal. 217-225, 2002.

[11] P. S. Hiremath dan J. R. Tegnoor, "Automatic Detection of Follicles in Ultrasound Images of Ovaries using Active Contours Method," Proc. IEEE Int. Conf. Comput. Intell. Comput. Res., no. January, hal. 28-29, 2010.

[12] Y. Deng, Y. Wang, dan Y. Shen, "An automated diagnostic system of polycystic ovary syndrome based on object growing," Artif. Intell. Med., vol. 51, no. 3, hal. 199209, 2011.

[13] P. S. Hiremath dan J. R. Tegnoor, "Fuzzy inference system for follicle detection in ultrasound images of ovaries," Soft Comput., vol. 18, no. 7, hal. 1353-1362, 2014.

[14] P. Mehrotra, C. Chakraborty, B. Ghoshdastidar, S. Ghoshdastidar, dan K. Ghoshdastidar, "Automated ovarian 
follicle recognition for polycystic ovary syndrome," ICIIP 2011 - Proc. 2011 Int. Conf. Image Inf. Process., no. Iciip, hal. 0-3, 2011.

[15] P. S. Hiremath dan J. R. Tegnoor, "Recognition of follicles in ultrasound images of ovaries using geometric features," 2nd Int. Conf. Biomed. Pharm. Eng. ICBPE 2009 - Conf. Proc., 2009.

[16] S. Rihana, H. Moussallem, C. Skaf, dan C. Yaacoub, "Automated algorithm for ovarian cysts detection in ultrasonogram," 2013 2nd Int. Conf. Adv. Biomed. Eng. ICABME 2013, no. 1, hal. 219-222, 2013.

[17] R. Saranya dan S. U. Maheswari, "Follicle detection in ovary image using adaptive particle swarm optimization," J. Med. Imaging Heal. Informatics, vol. 6, no. 1, hal. 125-132, 2016.

[18] M. Kass, A. Witkin, dan D. Terzopoulos, "Snakes: Active contour models," Int. J. Comput. Vis., vol. 1, no. 4, hal. 321-331, Jan 1988.

[19] T. F. Chan dan L. A. Vese, "Active Contours Without Edges," Br. Dent. J., vol. 142, no. 2, hal. 73, 2001.

[20] A. K. Mishra, P. W. Fieguth, dan D. A. Clausi, "Decoupled active contour (DAC) for boundary detection," IEEE Trans. Pattern Anal. Mach. Intell., vol. 33, no. 2, hal. 310-324, 2011. 